\title{
MEDIEVAL LEGAL REALISM
}

\author{
Pompeu Casanovas \\ (La Trobe Law School, Melbourne; UAB Institute of Law and Technology, Universitat Autònoma de Barcelona) \\ pompeu.casanovas@uab.cat \\ p.casanovasromeu@latrobe.edu.au
}

\begin{abstract}
This is a Research Note about the ongoing Project on the semantics of pact-modelling or pactism (pactisme) in Catalan ancient law. Pactism is the name of the legal doctrine that grounds the validity of legal provisions upon a pact-based model. It was developed as a basis for Catalan Public law in the $13^{\text {th }}, 14^{\text {th }}$ and $15^{\text {th }}$ centuries. We present it as a medieval realism. Looking at the concomitances of $20^{\text {th }}$ century legal realismand the doctrine of pactism can shed light on the emergence of early states and the construction of legal doctrines stemming from the reception of Roman law, the wide use of ius commune, and the development of case-based law and Scholastic reasoning methods. The semantics of pact-modelling processes and outcomes has yet to be established. Thus, it is also contended that Digital Humanities can offer some technological solutions to unravel underlying linguistic, cognitive, and ontological patterns to understand the political culture that came out of it and developed until the $18^{\text {th }}$ c. in Catalonia.
\end{abstract}

Keywords: legal realism, pactism, pact-based model, law as dialogue, Scholastics, Pragmatism, Digital Humanities, medieval law

Acknowledgements: Project IEC PRO2018-S05. Models del dret i la filosofia política catalanes: semàntica de les doctrines juridicopolítiques del pactisme en les seves diferents fases [Models of Catalan political philosophy and law: Semantics of pactmodel driven political and legal doctrines at their different stages].

Disclosure statement: No potential conflict of interest was reported by the authors.

License: This work is under Attribution-NonCommercial-ShareAlike 4.0 International (CC BY-NC-SA 4.0) https://creativecommons.org/licenses/by-nc-sa/4.0/

Suggested citation: Casanovas, P. (2019-2020). “Medieval Legal Realism”, Journal of Catalan Intellectual History 12: pp. 126134 DOI: $10.2478 /$ jocih-2019-0011

(C2021, Journal of Catalan Intellectual History

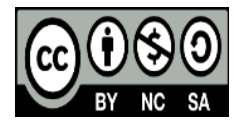




\section{LEGAL REALISM}

Talking about legal realism in the Middle Ages seems like making a historical mistake or a retrospective and undue projection of a legal doctrine of the $20^{\text {th }} \mathrm{c}$. onto a distant past. 'Medievalism' is a common term used to discredit such attempts. However, I will contend that a closer look might help researchers and legal historians to better understand the social and political behaviour that led to the construction of Medieval monarchies as early states. I am not asserting that 'realism' in Pragmatism and Scholastics has an identical meaning. This wasalready contested by Peirce (1905) himself in his rejection of the scholastic doctrine of universals. What I ampointing out in this note is that some of the features of the so-called legal realists in the $20^{\text {th }} \mathrm{c}$. can shed somelight on the empirical attitudes of the legal scholars that built the political doctrines of medieval public law, standing on ancient Catalan law and the scholastic Canon law. And in doing so, this approach can helpcontemporary researchers to understand the emergence of the early Catalan legal language-making and toolkit elaborated in the $12^{\text {th }}$ and $13^{\text {th }}$ centuries known as pactisme (in the Catalan language) or pact-based model, according to the felicitous English translation of Wendy R. Simon (this volume).

In the USA, 'legal realism' is the common name for the legal doctrines developed between 1880 and 1940 by leading judges such as Oliver W. Holmes (1841-1935) and Jerome Frank (1889-1957), legal scholars such as Roscoe Pound (1870-1964) and Karl Llewellyn (1893-1962), and eventually the mainstream of American legal philosophers in the $20^{\text {th }}$ century. In Europe, 'legal realism' denotes the Scandinavian legal school that stemming from Axel Hägerström (18681939) built the notions of law as fact, rights as an expectative of conduct, and legal belief. Alf Ross (1899-1979), Karl Olivecrona (1897-1980) and Vilhelm Lundstedt (1882-1955) are its main representatives.

Their political beliefs were quite diverse, stretching from totalitarianism to conservative liberalism and radical democracy. E.g., Olivecrona authoritative notion of the law contrasts with Ross's democratic stance'; and Pound's confidence on the construction of a 'civilised' legal order based on case-based law is opposite toFrank's direct confrontation with the supposed 'rationality' of legal decision-making. ${ }^{2}$

It is true that American realists leant on the figure and specific behaviour of judges and official officers, while Scandinavians were more interested in the inner cognitive process of generating expectations of conduct and decisions. To quote but one description by Max Radin (1931: 824), "law is what courts and partly irresponsible administrative agencies will do or say within the limits set by statutes and public opinion." Ross (1958) contended that legal rules-which cannot be neither true nor false - are directives, binding guidelines, addressed to judges to make decisions on specific cases. Either way, as stressed by contemporary research, both types of real-

\footnotetext{
${ }^{1}$ Olivecrona's Law as fact $(1939,1971)$ refers to the story of Tarquin (Lucius Tarquinius Superbus), who is said to have shown his son, Sextus, how to conquer the city of Gabii by cutting off the tallest poppies of his garden (i.e. beheading its leading men). This was more than an allegory, as Olivecrona defined law by means of power, and had shown some sympathies for the Germans in the inter-war period. On the contrary, Ross preferred a more nuanced approach, including legitimacy and, especially after World War II, human rights as necessary conditions.

${ }^{2}$ See Pound (1937) and Franck (1930, 1949). I highlighted Pound's link with Freud's psychological and cultural analysis in Casanovas (2013).
} 
ism share empirical epistemic attitudes and the willingness to get things done considering all the consequences of the decisions made (Pihlajamäki 2004). Being a realist means being also aware of the social environment that law tries to shape, acknowledging both the limitations of the whole process and the need to explain the course, reasons and causes of the decisions.

Tuori $(2007,2014)$ has shown how legal realists "revolutionized the study of early law and society from the 1920s to the 1960s by shifting attention from the 19th century formalistic preoccupation with written law codes and legal systems to a social relations and culture based approach". Explaining 'law in action' instead of 'law in books' became paramount. Even more recently Ignasi Terradas, revamping the salience of reciprocity in ancient law, has suggested that "in vindicatory societies the idea of justice stems from the social institutions that produce it" (Terradas 2019: 63). ${ }^{3}$

In feudal societies - such as the Catalan in the $11^{\text {th }}$ and $12^{\text {th }} \mathrm{c}$.- - feud, authorized vengeance, compositional procedures, and formal reconciliation were instruments of vindicatory justice. Attaining a reasonable balance and equipping itself with a judicial structure was crucial to guarantee a socially sustainable legal toolkit. We will contend that the emergence of an early state in the $13^{\text {th }}$ c. entailed a complex institution-building process, in which pact-based models and patterns were also supported by case-based law, Roman common law and - not surprisingly — the intellectual preeminence of Scholastics.

\section{MEDIEVAL LEGAL REALISM}

The link between Pragmatism and medieval legal doctrines has recurrently been noticed in the literature so far (Warbeke 1911, Mulligan 1946, Palmer 1956). Leo Strauss (1953) made a cause out of it. In recent times, law historians and legal philosophers are also starting to point out the close relationship between contemporary and medieval perspectives on law as fact and a casuistic and normative approach (Thévenin 2020). Likewise, several years ago, I realised that Catalan pactism - the legal doctrine that grounds the validity of legal provisions upon a pact-based model-looked like an early legal realism (Casanovas 2007, 2011). ${ }^{4}$

The dimensions of such a realism are less related to the theological instances of natural law than to the boundaries of power. Contrary to what would happen later in Europe, authority could not be solely concentrated in the hands of a monarch (or a state) but distributed along a social chain whose links could only stand in a perched precarious balance between several social groups. From the 13 c. onwards, the so-called Principality of Catalonia developed as a medieval state - the clerical consisting in the clergy, the military consisting in the nobility, and the royal

\footnotetext{
${ }^{3}$ The vindicatory system observes a homogeneity between offense and harm, which puts justice, rather than the legislative or contractual agreement, as the organizer of responsibility, until its total effectiveness. This may evoke an ideal of greater equity versus those of civil / criminal regulations." (Terradas 2019: 62).

${ }^{4}$ Contrary to other notions (such as 'mystical body'), 'pactism' is not a historical term that can be found in ancient official or doctrinal texts. It is a historiographical, not a historical notion, made up by the historian Josep Vicens Vives in the fifties, in the middle of Franco's dictatorship (Baydal Sala 2016). Baydal contends that it would be better to use concepts with a wider European scope, such as 'constitutionalism'. I don't think this is incompatible with the singularity of the Catalan case, which is comparable with other European regions which experienced similar social tensions and balances of power. See Pere Ripoll's comparative analysis on the Kortenberg Council of the Duchy of Brabant, the elects of the County of Venaissin, and the Deputation of the Kingdom of Navarra (Ripoll 2018).
} 
consisting in royal towns and cities (viles) of the country. The underlying social covenant entailed that law had to be grounded on the tension created by this kind of friction-reason, not just power; and negotiated individual agreements any time funds were needed to sustain public endeavours (such as wars of conquest or defence). This situation made it so that powers, the legal capacity to rule — of the king (princep), earls (barons) and cities (sindics) — had to be instantiated any time medieval courts convened. A 'mystical' political body was created across time to support political institutions and public law. The Crown of Aragon was a "community of communities", as asserted in many documents dated in the $13^{\text {th }}, 14^{\text {th }}$ and $15^{\text {th }} \mathrm{c}$. (Montagut Estragués 2012) , and collected and theorised by the doctrine of the most prominent legal scholars of the $16^{\text {th }}$ and $17^{\text {th }} \mathrm{c}$. (Ferro 2013).

Medieval constitutionalism entailed this kind of diverse and functional unity. The legal notions of Universitas Cataloniae or General de Catalunya (General of Catalonia) refer to the political dimension of the Catalan community (people, populus) through (i) legal pactism and (ii) a dual notion of Monarchy which, from the Courts held in Barcelona in 1283 onwards, was deemed to be the holder of jurisdictio generalis (Ripoll Sastre 2020; Montagut Estregués and Ripoll Sastre, 2020). What all this means is that the General's consent-i.e. the community's consent - was henceforth required to enact any general law. The legal motto spanned through the next centuries_-"In Cathalonia rex solus non condit leges, sed rex cum populo." (Maspons i Anglasell 1932, quoting Joan de Socarrats, $15^{\text {th }}$ c.)

The 'mystical body' also determined complex inner and external relationships. As for policies against heretics, while Jews and Muslims were increasingly aligned with the Canon law, the strategies for conversion figured out by the different orders of the Catholic Church (mainly Dominicans) grew increasingly. This implied the tacit construction of a matrix of dialogue and violence to deal with the religious outside through political and legal means (Macías, Casanovas and Zeleznikow 2020). As asserted by Halperin (1983: 466) some time ago, in medieval frontier societies silence was functional, as "silence about the implications of borrowing infidel institutions or respecting infidel customs was more effective in permitting such activity to continue than selfserving references to necessity or the circumscribed indulgences of Canon law or the Shar'ia".

It is worth mentioning the role of Scholastics and the casuistic led by crucial legal scholars such as Ramon de Penyafort (1175-1275), the Dominican who compiled the Decretals of Pope Gregory IX (1234) and exerted a great influence in the implementation of the brand-new Catholic

\footnotetext{
${ }^{5}$ T. de Montagut (2012: 112) quotes a direct excerpt of the Cort General de Montsó 1382-1384 [General Courts, Parliament] offered by Prince Martí to the Monarch Pere el Cerimoniós : "no solament en lo cors místic lo qual es compost de cap et de diverses membres distants, ans encara en lo cors qui viu en unitat de spirit" [not only in the mystical body which is made up of head and several distant members, but still in the body that lives in unit of spirit].

${ }^{6}$ In Catalonia the king alone does not make the law, but the king with the people. The traditional interpretation is the following: (i) Constitucions, laws proposed by the king, and approved by the branches; (ii) Capitols de Cort (Court Chapters), laws proposed by the branches and approved by the king; (iii) Actes de Cort (Court Acts), pacted acts with the acquiescence of branches. However, the most recent scholarship has shed light on the role of the branches: The legislative initiative always corresponded to them (braços), which normally presented it to the king as a súplica (supplication) in capitols (chapters). If the king enacted them only with the added formula of placet-plau al Senyor Rei, as it pleases the King - and nothing else was done, they became Court chapters. This clearly expressed the political dualism of the Catalan pactist constitution. Now, if these chapters were formally reworked in a unitary way, so that the resulting text was promulgated by the king himself using the Majestic Nos (We), then they were turned into Constitucions. (I am grateful to Tomàs de Montagut for providingme with this clarification).
} 
legal toolkit. Penyafort was at the crossroads of the state and the Church, and elaborated several doctrines in between, especially relevant for the emergence of dialogue as a new tool for conversion and for the doctrines of Christian just war and commercial relationships. The legal and political doctrine of pactism would have not been possible without the extended preparatory work of the jurists of the King's court, mainly formed in the Roman doctrines of the University of Bologna.

\section{THE PROJECTS ON PACT-MODELLING SEMANTICS}

Let's enumerate some of the features of this early realism: (i) limitations of King's rule in favour of a balance of power (dual Monarchy), (ii) valuing of negotiations, agreements and social and political covenants; (iii) consequentialism (attention to the consequences of legal decisions), (iv) holism (attention to the general framework), (v) settlement of all stakeholders (attention to the subjects involved), (vi) judicialism (involving reason, doctrine, and not just legal provisions). ${ }^{7}$ Another ancient brocard brought up by Maspons (1932) expresses the flexibility (and strength) of this pact-based model—pactes rompen lleis (agreements break laws).

Pactism is a legal technique based on jurisdictions and sources of law, with the double aspect of ancient legal norms and institutional organisation (Montagut i Estragués 1989). Historians of Catalan ancient law usuallyembrace a straightforward definition, meaning the political agreement by which kings were legally bound toconsider the consent and free will of their own subjects even if they could exert a jurisdictional power upon them (Ferro 2013: 22). Nevertheless, stemming from this technical notion, we deem possible to broaden it up.

We approach pactism from four different angles: (i) as a legal technique to build up the institutional structure of the state; (ii) as a legal technique of drafting public law (lleis paccionades); (iii) as a procedural technique to embed the Medieval Roman law-ius commune-into the structure of judicial reasoning (discretionary reasoning); (iv) as a strategy to extend Catalan merchant interests across the Mediterranean shores. ${ }^{8}$

We also can approach pactism as a system, i.e., as a set of rules, principles, values and evolving provisions that goes beyond the institutional structures to reach social objectives and create social bonds. From this latter point of view, we can understand it — as already said — as a conscious and reflective exercise of social engineering, i.e., as an early stage of legal realism.

The ongoing projects on dialogue as a source of law are focusing on this systemic and dynamic dimension, for the semantics of this pact-modelling processes and outcomes has yet to be established. Could we produce a systematic vocabulary, a lexicon, to be classified and reused in other researches? What kind of relationships could we discover? Are there some linguistic pat-

\footnotetext{
${ }^{7}$ The judicial oath of Catalan judges under Pere II (Const. vol. I 1l. 1, ti. 48, llei 8, 1283) reads: « ... e los plets qui vendran en mon poder espatxaré, de mon poder, com pus tost poré, segons Dret e rahó. » Case-based law was going to be issued "according to Law and reason".

${ }^{8}$ El Llibre de Consolat de Mar (1320-1330) Book of the Consulate of the Sea is a compendium of maritime law for governing trade in the Mediterranean and establishing permanent relations (consulates) in Mediterranean countries. This kind of networking and commercial bonds points at a cultural pattern that emerged much later as well, e.g., in the relationships with Latin-American countries in the $19^{\text {th }}$ c. (Harrington 2019).
} 
terns ready to be reused as cultural legal bricks? What are the ontological elements? Which pragmatic link can we establish between them and the practice of ancient Catalan law? And what is the role of the inner and outer environments, i.e., the internal relationships with subjects ruled by different personal and community laws — such as the Jews - , and the complex external relationships with the Roman Church, with the surrounding kingdoms, and with the Mediterranean Islamic countries?

It is our contention that Digital Humanities might have a prominent role in finding plausible answers to these research questions. ${ }^{9}$ A fundamental question is "how humanities datasets can be represented digitally, in such a way that machines can process them, understand their meaning, facilitate their inquiry, and exchange them onthe Web" (Meroño-Peñuela 2017: 144). A research tradition in analysing Catalan Ancient Texts - mainly focused on Catalan medieval literaturedoes exist already (Torruella 1989, 2009). ${ }^{10}$ CICA contains a section of legal and political texts that can certainly be used to test some of our preliminary hypothesis. E.g., one of the main documents about legal pactism —El Dotzè del Crestià, by Eiximenis— has been partially digitised.

In the annual Scientific Workshops held in 2018 and 2019 at IEC $^{11}$, researchers in Artificial Intelligence (AI), natural language processing (NLP), knowledge graphs (KG), the web of data (WD), and ontology building, pointed out some actions to be taken in the next future. The engagement of AI researchers with ancient Catalan thinking is not new. We may remember the studies published by Alexander Fidora and Carles Sierra on Ramon Llull's (Lullius) early graphs (Fidora and Sierra, 2011).

The recent discovery by Pere Ripoll of El llibre dels Vuit Senyals [The Book of Eight Signals] (LVS) in the Archives of the Crown of Aragon is helping us to get a sound starting point for a computer-based analysis. This book was compiled in the $15^{\text {th }} \mathrm{c}$. between 1415 and 1425 as a summary of the ancient laws of the land before 1413-1423. It was the precedent of El llibre dels Quatre Senyals [The Book of Four Signals] (LQS) (Montagut i Estragués 2006), also compiled in the $15^{\text {th }} \mathrm{c}$. to summarise the financial and political legislation of the Diputaciódel General. Both books reflect the structural rulings and organization of the institution in a time of change and political threat - i.e. first, the change of dynasty (the Trastámara house), and later the construction of the Spanish(absolutist) state based on Castilian's laws. ${ }^{12}$

Several analytical lines have been identified. Among others: (i) a description of old Catalan

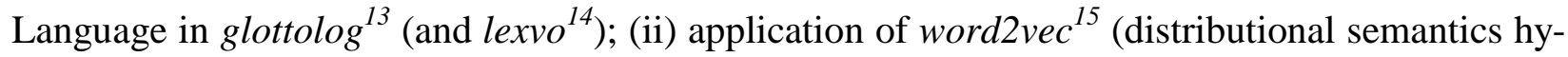

\footnotetext{
${ }^{9}$ See the survey of technologies and SW methods carried out by Meroño-Peñuela et al. (2015).

${ }^{10}$ Computerised Corpus of Old Catalan (Corpus Informatitzat del Català Antic, CICA), http://www.cica.cat/

${ }^{11}$ Researchers who participated and contributed to the discussions organised by J. Monserrat and P. Casanovas were, in alphabetical order, Joan Cuscó (UB), Jorge González-Conejero (IDT-UAB), Mario Macías (IDT- UAB), Albert Meroño-Peñuela (Vrije Universiteit Amsterdam-now at Kings's College, London), Tomàs de Montagut Estragués (UPF), Elena Montiel Ponsoda (UPM), Pablo Noriega (IIIA-CSIC), Nardine Osman (IIIA- CSIC), Enric Plaza (IIIA-CSIC), Marta Poblet (RMIT), Victor Rodriguez Doncel (UPM), Pere Ripoll Sastre (UPF), Vicent Salvador (UJI), Carles Sierra (IIIA-CSIC), Wendy R. Simon (UAO and IDT-UAB), Joan Tello (UB), Emma Teodoro (IDT-UAB), Joan-Josep Vallbé (UB) and Josep M. Vilajosana (UB).

${ }^{12}$ See Ripoll Sastre $(2018,2020)$ and Montagut Estragués (2006).

${ }^{13} \mathrm{https}$ ://glottolog.org/

14 http://www.lexvo.org/

15 https://en.wikipedia.org/wiki/Word2vec
} 
pothesis), Word2vec/embeddings (distributed representation of words: continuous bag-of-words (CBOW) or continuous skip-gram); (iii) linguistic patterns discovery; (iv) generation of an Ontology Design Pattern (ODP) ${ }^{16}$; (v) probabilistic topic models application; (vi) discourse analysis to frame the possible interpretations. Comparative linguistic and historical work-Catalan forensic and court language - have also been planned. In the same vein, the conceptual analysis of legal Islamic, Jewish and Catholic texts is required to make full sense of the findings.

Pact-modelling semantics is an exciting research challenge, encompassing several types of relevant expert knowledge and analytical tools. At the time of writing this Note, we had thought we could offer some results. We are still slowly recovering our research pulse, after a difficult time. We will do better in the years to come.

\section{REFERENCES}

Baydal Sala, V. 2016. "Pactistes des de quan? Les arrels del concepte de «pactisme» en la historiografia catalana i l'obra de Jaume Vicens Vives", eHumanista/IVITRA, 9: 314-340.

Casanovas, P. 2011. "Catalan legal mind and the legal Catalan mind: a brief overview of legal and political principles." Journal of Catalan Intellectual History 1 (2): 161-177. The original text was written as an invited lecture to the Symposium Mediterranean Mirror: Catalan Law in an International Context, held at the Elmer Holmes Bobst Library, New York University, on April 27th, 2007.

Casanovas, P. 2013."Sobre la palesa insuficiència dels nostres mètodes per regular les relacions humanes." [On the obvious inadequacy of our methods for regulating human relations]. Lecture at UAB, 6 May. https://ddd.uab.cat/pub/estudis/2013/106749/sobpalinsmet_a2013.pdf

Casanovas, P. 2019. "Catalan Identities: Language, Power and Political Pactism from a Historical Perspective." In The Rise of Catalan Identity. Social Commitment and political engagement in the $20^{\text {th }} \mathrm{c}$. Eds. Pompeu Casanovas, Montserrat Corretger, Vicent Salvador. Cham: Springer, pp. 19-48.

Ferro i Pomà, V. 2013. "El Dret català durant els segles XVI i XVII." Revista de Dret Històric Català, 12: 9- 108.

Fidora, A. and Sierra, C. (ed.). 2011. Ramon Llull, from the Ars Magna to Artificial Intelligence. Barcelona: Artificial Intelligence Research Institute.

Frank, J. 1930. Law and the Modern Mind. N.Y.: Transaction Publishers.

Frank, J. 1949. Courts on Trial. Princeton, NJ: Princeton University Press.

Halperin, C. J. 1984. "The ideology of silence: Prejudice and pragmatism on the medieval religious frontier". Comparative Studies in Society and History, 26(3): 442-466.

Harrington, T. 2019. "When the Mediterranean Moved West: Catalan Social Networks and the Construction of Nineteenth-and Early Twentieth-Century Uruguayan Society and Culture" in Transatlantic Studies: Latin America, Iberia, and Africa. Eds., Cecilia Enjuto-Rangel, Sebastia An Faber, Pedro García-Caro and Robert P. Newcomb. Liverpool: Liverpool University Press.

\footnotetext{
${ }^{16}$ http://ontologydesignpatterns.org/wiki/Main_Page
} 
Macías, M., Casanovas, P., Zeleznikow, J. 2020. "Shevirath Ha-Kelim. Jewish Mysticism and the Catalan Matrix for Dialogue and Conflict". JOCIH, 12: 59-92.

Maspons i Anglasell, F. de P. 1932. L'esperit del Dret Públic català. Barcelona: Barcino.

Meroño-Peñuela, A., Ashkpour, A., Van Erp, M., Mandemakers, K., Breure, L., Scharnhorst, A., Schlobach, S. and Van Harmelen, F. 2015. "Semantic technologies for historical research: A survey". Semantic Web, 6 (6): 539-564.

Meroño-Peñuela, A., 2017. Digital humanities on the Semantic Web: accessing historical and musical linked data. Journal of Catalan Intellectual History, 1 (11): 144-149.

Montagut i Estragués, T. de. 1989. "Pactisme o absolutisme a Catalunya: les grans institucions de govern (s. XV- XVI)". Anuario de estudios Medievales, 19: 669-680.

Montagut i Estragués, T. de (ed.). 2006 [1634]. Llibre dels quatre senyals (edició facsímil, 2 Vol.). Barcelona: Editorial Base i Enciclopèdia Catalana [1634].

Montagut i Estragués, T. de. 2012. "La constitució política de la Corona d'Aragó" in El Compromiso de Caspe (1412), cambios dnásticos y Constituciones políticas en la Corona de Aragón. Ed., María Isabel Falcón Pérez. Zaragoza: Cortes de Aragón, Gobierno de Aragón e Ibercaja, pp. 104-116.

Montagut i Estragués, T. de, Ripoll Sastre, P. 2020. "Pactism in Catalonia: a dual conception of the political community". JOCIH, 12: 17-29 (this volume).

Mulligan, R.W. 1946. “A Note on Legal Pragmatism”, Thought: Fordham University Quarterly, 21 (3): 513- 522.

Olivecrona, K. 1971 [1939]. Law as Fact. London: Stevens \& Sons.

Palmer, B.W. 2016. "The Natural Law and Pragmatism". The Catholic Lawyer, 2 (2): 150-160. Peirce, C.S. 1905. "What pragmatism is", The monist, 15 (2): 161-181.

Pound, R. 1937. "The Future of Law". Yale LJ 47 (1): 1-13.

Pihlajamäki, H. 2004. "Against metaphysics in law: The historical background of American and Scandinavian legal realism compared." The American Journal of Comparative Law, 52 (2): 469-487.

Radin, M. 1931. "Legal Realism " Columbia Law Review, 31 (5): 824-828.

Ripoll Sastre, P. 2018. Llibre de vuit senyals (15th century): an edition, legal and comparative study. Doctoraldissertation, Universitat Pompeu Fabra.

Strauss, L. 1953. Natural Right and History. Chicago: University of Chicago Press.

Terradas, I. 2019. La justicia más antigua: teoría y cultura del ordenamiento vindicatorio. Madrid: CSIC.

Thévenin., P. 2020. "Fact as Law. An Archeology of Legal Realism". In The Discovery of the Fact. Eds. CliffordAndo and William P. Sullivan. University of Michigan Press, p. 175-221.

Torruella Casañas, J. 2019. "Los ejes principales en el diseño de un corpus diacrónico: el caso del CICA". In A survey of corpus-based research. Eds., Pascual Cantos Gómez and Aquilino Sánchez Pérez. Online, p. 21-36, https://www.um.es/lacell/aelinco/contenido/pdf/2.pdf

Tuori, K. 2007. "Legal Realism and Early Law: The influence of American legal doctrine in the 


study of non-Western law 1920-1960.” 16 October,
http://www.law.nyu.edu/sites/default/files/upload_documents/hrstuoripaper.pdf

Tuori, K. 2014. Lawyers and Savages: Ancient History and Legal Realism in the Making of Legal Anthropology.London: Routledge.

Warbeke, J. 1919. “A medieval aspect of pragmatism”, The Journal of Philosophy, Psychology and Scientific Methods, 16 (8): 207-215. 